\title{
THE STRUCTURE OF A201A, A NOVEL NUCLEOSIDE ANTIBIOTIC
}

\author{
H. A. Kirst, D. E. Dorman, J. L. Occolowitz, N. D. Jones, \\ J. W. Paschal, R. L. Hamill and E. F. Szymanski \\ The Lilly Research Laboratories, Eli Lilly and Company \\ Indianapolis, Indiana 46285, U.S.A.
}

(Received for publication November 20, 1984)

\begin{abstract}
The structure of the novel nucleoside antibiotic A201A has been determined by a combination of chemical and spectroscopic methods. It is composed of 6-dimethylaminopurine, 3-amino-3-deoxyribose, $p$-hydroxy- $\alpha$-methylcinnamic acid, a novel unsaturated hexofuranose and 3,4-di- $O$-methylrhamnose. Structures have also been assigned to several related minor factors simultaneously isolated from the fermentation broth. These unique nucleosides have very interesting similarities and differences in structure with the known antibiotics puromycin and hygromycin $\mathrm{A}$.
\end{abstract}

Fermentation of a new strain of Streptomyces capreolus, NRRL 3817, (based on cell wall analyses, this initial classification of Streptomyces should probably be changed: F. MERTz, personal communication) has produced predominantly a single new antibiotic which is highly active in vitro against Gram-positive bacteria. The gross structure of this antibiotic, designated A201A, was deduced by spectroscopic and chemical methods. ${ }^{1)} \quad$ These studies indicated that A201A was a nucleoside with a very unique structure, resembling puromycin to a limited degree, but also differing from it in several important ways. ${ }^{2)} \quad$ The structure of A201A has now been unambiguously defined (see Fig. 1) and is reported in this paper along with the structures of several minor factors isolated from the fermentation broth which are structurally related to A201A.

\section{Results and Discussion}

A201A was readily extracted into chloroform from broth filtrate obtained from the fermentation of a strain of $S$. capreolus. Purification was then accomplished by chromatography on silica gel and subsequent crystallization from acetone. It was obtained as a white solid, mp $170 \sim 172^{\circ} \mathrm{C}$, soluble in methanol, acetone, chloroform, ethyl acetate, acetonitrile, tetrahydrofuran, $0.1 \mathrm{~N} \mathrm{HCl}$ and $0.1 \mathrm{~N}$ $\mathrm{NaOH}$, but insoluble in hexane, toluene, diethyl ether and water. It gave a negative reaction with Benedict reagent, Fehling solution, ferric chloride and ceric ammonium nitrate, and a slow but not immediate reaction with periodate, Tollen reagent and 2,4-dinitrophenylhydrazine. It had a strong UV chromophore and complex proton and ${ }^{13} \mathrm{C}$ NMR spectra.

The empirical formula of $\mathrm{C}_{37} \mathrm{H}_{50} \mathrm{~N}_{6} \mathrm{O}_{14}$ (MW 802) was deduced from elemental analyses of A201A and high resolution mass spectrometry of two derivatives prepared by hydrogenation. Although the largest fragment of A201A in its EI mass spectrum was $m / z$ 454, dihydro A201A and tetrahydro A201A, the latter defined by quantitative microhydrogenation, exhibited parent ions at $m / z \quad 804$ and 806 respectively. The composition of these ions was determined by high resolution measurements and the empirical formula of the parent compound was thereby established by subtracting the appropriate number of hydrogen atoms. Later, the field desorption mass spectrum of A201A was obtained which confirmed the molecular weight of 802 (Mr. CARTER COOK, University of Illinois, personal communi- 
Fig. 1. Structure of A201A.

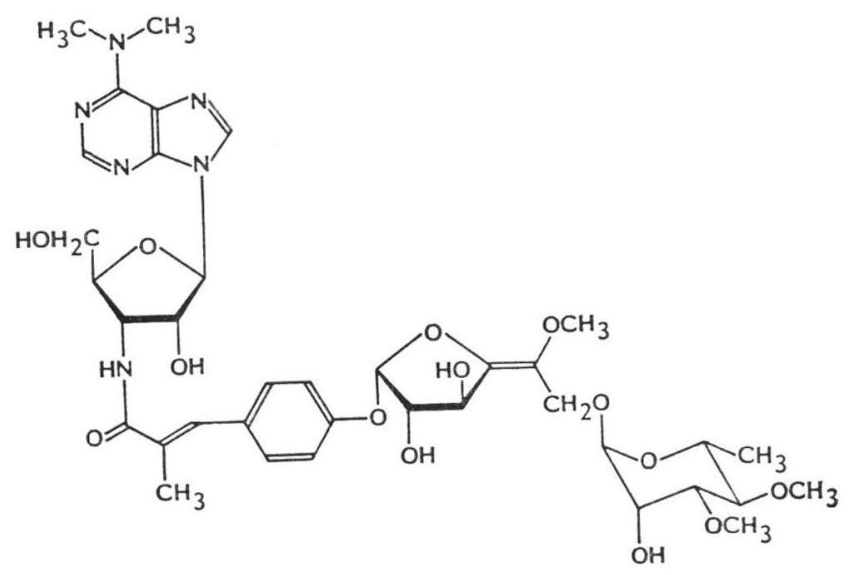

cation).

These mass spectrometric studies also established that the dihydro A201A produced by hydrogenation resulted from saturation of the cinnamamide double bond rather than from reduction of the hexofuranose double bond. Reduction of the cinnamamide double bond was not stereospecific for either dihydro A201A or tetrahydro A201A, as determined by both TLC and NMR analyses. Although not observed from hydrogenation of A201A, the isomeric dihydro A201A, in which the hexofuranose double bond is saturated, has been isolated from the fermentation broth as a minor component (A201E, see below). Acidic hydrolysis of A201A yielded 6-dimethylaminopurine, identified by comparison with an authentic sample. The isolation of this component suggested a nucleoside structure, which was supported by the presence of ions at $m / z 222\left(\mathrm{C}_{8} \mathrm{H}_{12} \mathrm{~N}_{5} \mathrm{O}_{2}\right), 206\left(\mathrm{C}_{8} \mathrm{H}_{12} \mathrm{~N}_{5} \mathrm{O}\right)$, $192\left(\mathrm{C}_{8} \mathrm{H}_{10} \mathrm{~N}_{5} \mathrm{O}\right)$ and $163\left(\mathrm{C}_{7} \mathrm{H}_{8} \mathrm{~N}_{5}\right)$ in the electron impact mass spectrum of A201A. ${ }^{3)}$ This information, combined with the very facile cleavage of A201A in the mass spectrometer into fragments of $m / z 454\left(\mathrm{C}_{22} \mathrm{H}_{26} \mathrm{~N}_{6} \mathrm{O}_{5}\right)$ and $292\left(\mathrm{C}_{15} \mathrm{H}_{18} \mathrm{NO}_{5}\right)$, strongly suggested a nucleoside structure with three major components of the general composition: $\left(\mathrm{C}_{7} \mathrm{H}_{8} \mathrm{~N}_{5}\right)-\left(\mathrm{C}_{15} \mathrm{H}_{17} \mathrm{NO}_{5}\right)-\left(\mathrm{C}_{15} \mathrm{H}_{25} \mathrm{O}_{9}\right)$.

During purification of A201A by silica gel chromatography, a compound less polar than A201A with a molecular weight of 454 and composition of $\mathrm{C}_{22} \mathrm{H}_{26} \mathrm{~N}_{6} \mathrm{O}_{5}$ was isolated. It is not known if this compound was a true fermentation product or an artifact produced by hydrolysis of A201A during isolation procedures. Nevertheless, the structural resemblance of this smaller molecule to A201A was readily apparent from spectroscopic comparisons. From ${ }^{1} \mathrm{H}$ and ${ }^{13} \mathrm{C} \mathrm{NMR}$ studies, the structure of this smaller component (hydrolysis product 1) was deduced to be that shown in Fig. 2 (see Tables 1 and 2 for NMR data). Interestingly, both $\mathbf{1}$ and its $O$-methyl derivative $\mathbf{2}$ were devoid of antibiotic activity in vitro.

The presence of the postulated aromatic acid was confirmed by basic hydrolysis of A201A, which yielded $p$-hydroxy- $\alpha$-methylcinnamic acid identical in all respects to a sample prepared by known procedures. ${ }^{4,5)}$ The methyl group and aromatic ring on the double bond are cis to each other in both A201A and hydrolysis product $\mathbf{1}$, as evidenced by the demonstration of a nuclear Overhauser effect (NOE) between the methyl group and ortho ring protons and the absence of an NOE between the methyl group and vinyl proton.

All efforts to isolate 3-amino-3-deoxyribose from either A201A or 1 were unsuccessful. However, 
Table 1. ${ }^{1} \mathrm{H}$ NMR chemical shifts and coupling constants of A201A and related factors. ${ }^{\mathrm{a}}$

\begin{tabular}{|c|c|c|c|c|c|c|}
\hline & & A201A & $\begin{array}{c}\text { Hydrolysis } \\
\text { product } \mathbf{1}\end{array}$ & A201C & A201D & A201E \\
\hline \multirow{3}{*}{$\begin{array}{l}\text { Adenine } \\
\text { moiety }\end{array}$} & $\mathrm{H} 2$ & $8.46(\mathrm{~s})$ & 8.47 & 8.47 & 8.47 & 8.47 \\
\hline & $\mathrm{H} 8$ & $8.24(\mathrm{~s})$ & 8.23 & 8.23 & 8.23 & 8.23 \\
\hline & $\mathrm{CH}_{3}$ & $3.47(\mathrm{~s})$ & 3.47 & 3.47 & 3.47 & 3.46 \\
\hline \multirow{8}{*}{$\begin{array}{l}\text { Aminopentose } \\
\text { moiety }\end{array}$} & $\mathrm{H} 1$ & $6.05(2.5)$ & 6.05 & 6.04 & 6.04 & 6.04 \\
\hline & $\mathrm{H} 2$ & $4.56(\mathrm{~m})$ & 4.55 & 4.55 & 4.58 & 4.55 \\
\hline & $2-\mathrm{OH}$ & $5.95(4.5)$ & 5.95 & 5.95 & 5.96 & 5.94 \\
\hline & $\mathrm{H} 3$ & $4.60(\mathrm{~m})$ & 4.55 & 4.55 & 4.58 & 4.55 \\
\hline & $3-\mathrm{NH}$ & $7.83(7)$ & 7.77 & 7.85 & 7.75 & 7.83 \\
\hline & $\mathrm{H} 4$ & $4.22(\mathrm{~m})$ & 4.22 & b & 4.24 & 4.24 \\
\hline & H5 & $3.59,3.77(13)$ & 3.70 & b & $3.6 \sim 3.75$ & b \\
\hline & $5-\mathrm{OH}$ & 5.22 & 5.20 & 5.20 & 5.21 & 5.20 \\
\hline \multirow{5}{*}{$\begin{array}{l}\text { Aromatic acid } \\
\text { moiety }\end{array}$} & $\mathrm{CH}_{3}$ & $2.05(1)$ & 2.04 & 2.04 & 2.05 & 2.04 \\
\hline & Vinyl & $7.27(1)$ & 7.23 & 7.2 & 7.27 & 7.25 \\
\hline & $\mathrm{H} 2, \mathrm{H} 6$ & $7.08,7.17$ & $6.76,6.85$ & $6.83,6.90$ & $7.07,7.16$ & $7.01,7.10$ \\
\hline & $\mathrm{H} 3, \mathrm{H} 5$ & $7.27,7.36$ & $7.22,7.31$ & 7.09 & $7.36,7.45$ & $7.32,7.41$ \\
\hline & $\mathrm{OH}$ & - & 9.66 & 8.9 & - & - \\
\hline \multirow{8}{*}{$\begin{array}{l}\text { Hexofuranose } \\
\text { moiety }\end{array}$} & $\mathrm{H} 1$ & $5.86(4)$ & - & 5.83 & 5.83 & 5.52 \\
\hline & $\mathrm{H} 2$ & $4.10(\mathrm{~m})$ & - & b & 4.1 & $<4.2$ \\
\hline & $2-\mathrm{OH}$ & $5.57(6.5)$ & - & b & 5.52 & 5.33 \\
\hline & $\mathrm{H} 3$ & $4.55(\mathrm{~m})$ & - & 4.55 & 4.58 & $<4.1$ \\
\hline & $3-\mathrm{OH}$ & $5.65(7)$ & - & 5.68 & 5.52 & 5.33 \\
\hline & $5-\mathrm{OCH}_{3}$ & $3.49(\mathrm{~s})$ & - & 3.51 & 3.51 & 3.19 \\
\hline & $\mathrm{H} 6$ & $4.01,4.32(12)$ & - & $\mathrm{b}$ & 4.06 & $\mathrm{~b}$ \\
\hline & $6-\mathrm{OH}$ & - & - & - & 4.53 & - \\
\hline \multirow{9}{*}{$\begin{array}{l}\text { Rhamnose } \\
\text { moiety }\end{array}$} & $\mathrm{H} 1$ & $4.68(2)$ & - & 4.68 & - & 4.59 \\
\hline & $\mathrm{H} 2$ & $3.84(\mathrm{~m})$ & - & $\mathrm{b}$ & - & $\mathrm{b}$ \\
\hline & $2-\mathrm{OH}$ & $4.85(4.5)$ & - & 4.87 & - & 4.87 \\
\hline & H3 & $3.22(\mathrm{dd}, 3,9)$ & - & 3.19 & - & $\mathrm{b}$ \\
\hline & $3-\mathrm{OCH}_{3}$ & $3.29(\mathrm{~s})$ & - & 3.30 & - & 3.29 \\
\hline & $\mathrm{H} 4$ & $3.02(\mathrm{dd}, 9,9)$ & - & 3.02 & - & 3.00 \\
\hline & $4-\mathrm{OCH}_{3}$ & $3.40(\mathrm{~s})$ & - & 3.40 & - & 3.39 \\
\hline & $\mathrm{H} 5$ & $3.55(\mathrm{~m})$ & - & b & - & b \\
\hline & H6 & $1.17(6)$ & - & 1.16 & - & 1.14 \\
\hline
\end{tabular}

a Measured in dry DMSO- $d_{6}$; chemical shifts are in $\delta$ values downfield from external tetramethylsilane; coupling constants for A201A, given in parentheses, are in $\mathrm{Hz}$.

b Not assigned.

its presence was established by comparison of a derivative of 1 with a sample of known structure prepared from puromycin aminonucleoside, previously proven to contain D-3-amino-3-deoxyribose. ${ }^{\text {) }}$ To accomplish this, the 3 -amino group of puromycin aminonucleoside was acylated with the $N$-hydroxysuccinimide ester of $p$-methoxy- $\alpha$-methylcinnamic acid $^{4,7)}$ to yield the derivative 2 (Fig. 3). The product, prepared in this unambiguous manner, was then compared with the derivative of $\mathbf{1}$ obtained by methylation of the phenolic group with diazomethane. The two products were identical in all respects, including circular dichroism spectra, thereby confirming the identity of the amino sugar as D-3-amino-3-deoxyribose. This established the complete structure of $\mathbf{1}$ and a partial structure for A201A.

Acidic hydrolysis of A201A followed by acetylation and silica gel chromatography yielded 1,2-di$O$-acetyl-3,4-di- $O$-methylrhamnose. Comparison with an authentic sample prepared from $\mathrm{L}-(+)-$ rhamnose $^{8 \sim 11)}$ showed the two products were identical in all respects except the sign of optical rotation. 
Table 2. ${ }^{13} \mathrm{C}$ NMR chemical shifts of A201A and related factors. ${ }^{\mathrm{a}}$

\begin{tabular}{|c|c|c|c|c|c|c|}
\hline & & A201A & $\begin{array}{l}\text { Hydrolysis } \\
\text { product } \mathbf{1}\end{array}$ & & & A201A \\
\hline \multirow{7}{*}{$\begin{array}{l}\text { Adenine } \\
\text { moiety }\end{array}$} & $\mathrm{C} 2$ & 151.7 & 151.7 & \multirow{7}{*}{$\begin{array}{l}\text { Hexofuranose } \\
\text { moiety }\end{array}$} & $\mathrm{C} 1$ & $99.6^{b}$ \\
\hline & $\mathrm{C} 4$ & 149.5 & 149.5 & & $\mathrm{C} 2$ & 72.7 \\
\hline & $\mathrm{C} 5$ & 119.5 & 119.6 & & $\mathrm{C} 3$ & 76.3 \\
\hline & C6 & 154.2 & 154.2 & & $\mathrm{C} 4$ & 132.0 \\
\hline & $\mathrm{C} 8$ & 137.7 & 137.7 & & $\mathrm{C} 5$ & 143.1 \\
\hline & $\mathrm{CH}_{3}$ & 37.8 & 37.8 & & C6 & 62.3 \\
\hline & & & & & $\mathrm{CH}_{3}$ & 57.3 \\
\hline \multirow{6}{*}{$\begin{array}{l}\text { Aminopentose } \\
\text { moiety }\end{array}$} & $\mathrm{Cl}$ & 89.3 & 89.3 & & & \\
\hline & $\mathrm{C} 2$ & 73.1 & 73.2 & \multirow{13}{*}{$\begin{array}{c}\text { Rhamnose } \\
\text { moiety }\end{array}$} & $\mathrm{C} 1$ & $99.3^{\mathrm{b}}$ \\
\hline & $\mathrm{C} 3$ & 50.7 & 50.7 & & $\mathrm{C} 2$ & 66.1 \\
\hline & $\mathrm{C} 4$ & 82.7 & 82.7 & & $\mathrm{C} 3$ & 80.7 \\
\hline & $\mathrm{C} 5$ & 60.7 & 60.7 & & $\mathrm{C} 4$ & 81.2 \\
\hline & & & & & $\mathrm{C} 5$ & 67.0 \\
\hline \multirow{8}{*}{$\begin{array}{l}\text { Aromatic acid } \\
\text { moiety }\end{array}$} & $\mathrm{C}=\mathrm{O}$ & 169.3 & 169.4 & & C6 & 17.7 \\
\hline & $\mathrm{CH}_{3}$ & 14.3 & 14.3 & & $\mathrm{CH}_{3}$ & 55.8 \\
\hline & $\alpha-\mathrm{C}$ & 130.7 & 126.7 & & $\mathrm{CH}_{3}$ & 59.8 \\
\hline & $\beta-\mathrm{C}$ & 132.2 & 132.9 & & & \\
\hline & $\mathrm{C} 1$ & 129.9 & 128.9 & & & \\
\hline & $\mathrm{C} 2, \mathrm{C} 6$ & 130.7 & 130.9 & & & \\
\hline & $\mathrm{C} 3, \mathrm{C} 5$ & 116.2 & 115.2 & & & \\
\hline & $\mathrm{C} 4$ & 156.0 & 157.1 & & & \\
\hline
\end{tabular}

a Measured in DMSO relative to external tetramethylsilane.

b Values may be interchanged.

Fig. 2. Comparison with puromycin.<smiles>COc1ccc(CCNC(=O)NC2C(O)C3OC2(CO)C3n2cnc3c(N(C)C)ncnc32)cc1</smiles>

Puromycin

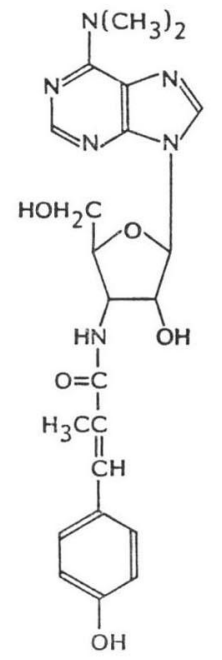

Hydrolysis product 1

Hence, A201A contains 3,4-di- $O$-methyl-Drhamnose. NMR studies confirmed it as the terminal sugar in A201A and indicated the anomeric linkage was $\alpha$.

By subtracting the compositions of the four identified moieties from the empirical formula of A201A, the unidentified unit was deduced to have the composition $\mathrm{C}_{7} \mathrm{H}_{10} \mathrm{O}_{4} \cdot{ }^{1} \mathrm{H}$ and ${ }^{13} \mathrm{C}$ NMR studies located the resonances of the unidentified unit and suggested its structure was an unsaturated saccharide moiety.

Ozonolysis of A201A yielded two products, di- $O$-methylrhamnose coupled to three of the seven carbon atoms of the unsaturated sugar (compound 3, Fig. 4) and nucleoside compound 1. No other compounds were found to account for the fate of the four missing carbon atoms; ozonolysis of the glycosidic bond and subsequent degradation is the most probable explanation. ${ }^{12}$ Cleavage of the double bond by photo-oxygenation ${ }^{13)}$ also yielded compounds $\mathbf{1}$ and $\mathbf{3}$ and suggested the formation of a third product (TLC analysis), but all attempts to isolate the latter were unsuccessful. A201A was also degraded to 1 by $m$-chloroperbenzoic acid. Although hydrogenation of A201A over $\mathrm{PtO}_{2}$ yielded principally tetrahydro A201A, a modest amount of dihydro 1 was also obtained, sug- 
Fig. 3. Synthesis of nucleoside derivatives.<smiles>COc1ccc(C=C(C)C(=O)OCc2ccccc2)cc1</smiles>

Hydrolysis product 1

$\mathrm{CH}_{2} \mathrm{~N}_{2}$<smiles>COc1ccc(C=C(C)C(=O)NC2C(O)C3OC2(CO)C3n2cnc3c(N(C)C)ncnc32)cc1</smiles>

2

Fig. 4. Reactions of unsaturated sugar of A201A.

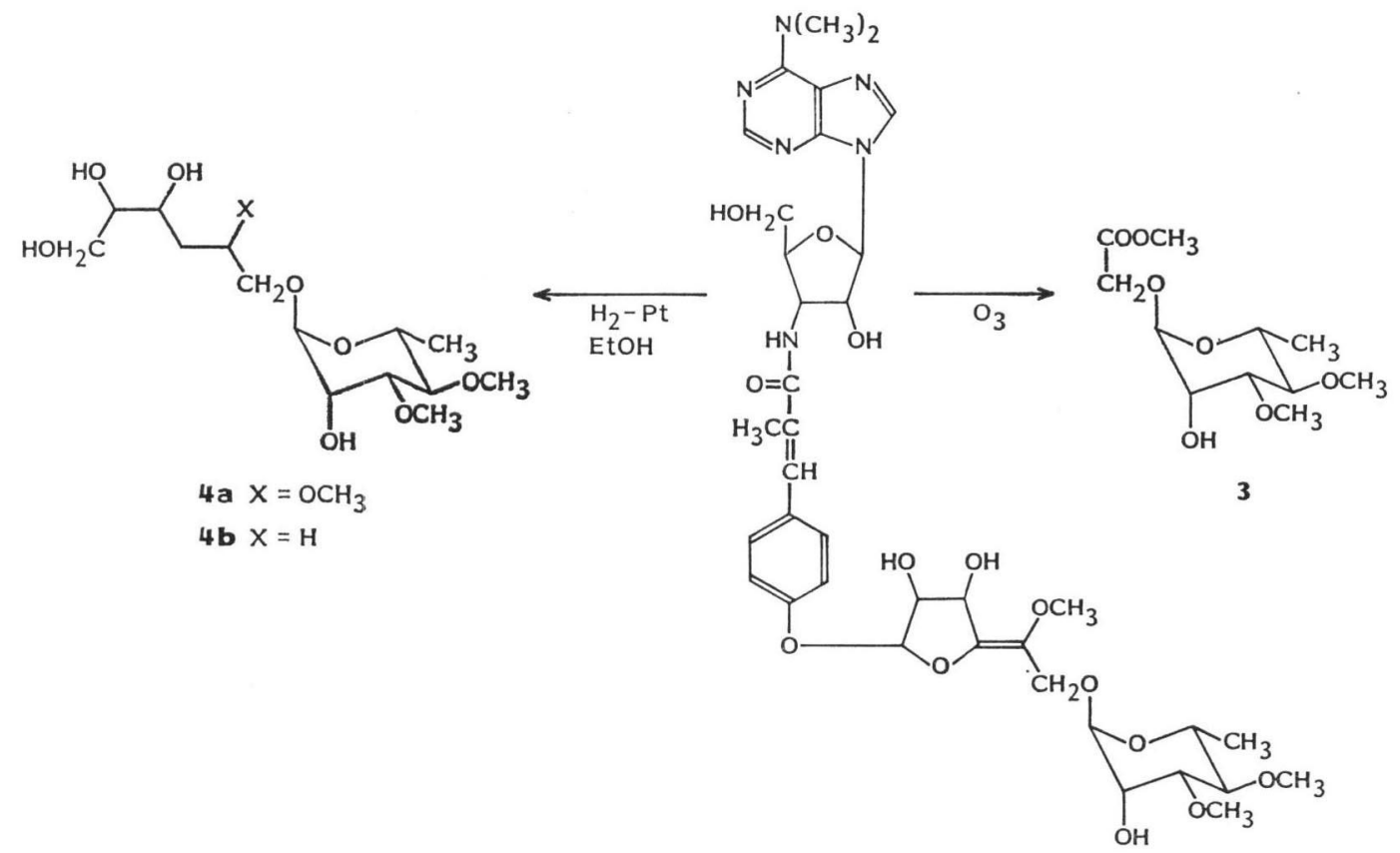

gesting that some hydrogenolysis had occurred in addition to reduction of the double bonds. Tetrahydro A201A was stable under these conditions. Isolation of the hydrogenolysis products by chromatography yielded very small amounts of two different derivatives of di- $O$-methylrhamnose. Their structures were deduced to be $4 \mathrm{a}$ and $4 \mathrm{~b}$ from the NMR and mass spectra of the compounds and their tetra-acetyl derivatives. The products from these ozonolysis and hydrogenolysis experiments suggested a furanose structure containing an exocyclic double bond with a methoxyl group attached to it. However, the stereochemistry of the unsaturated sugar could not rigorously be established. 
Fig. 5. X-Ray analysis of A201A derivative.

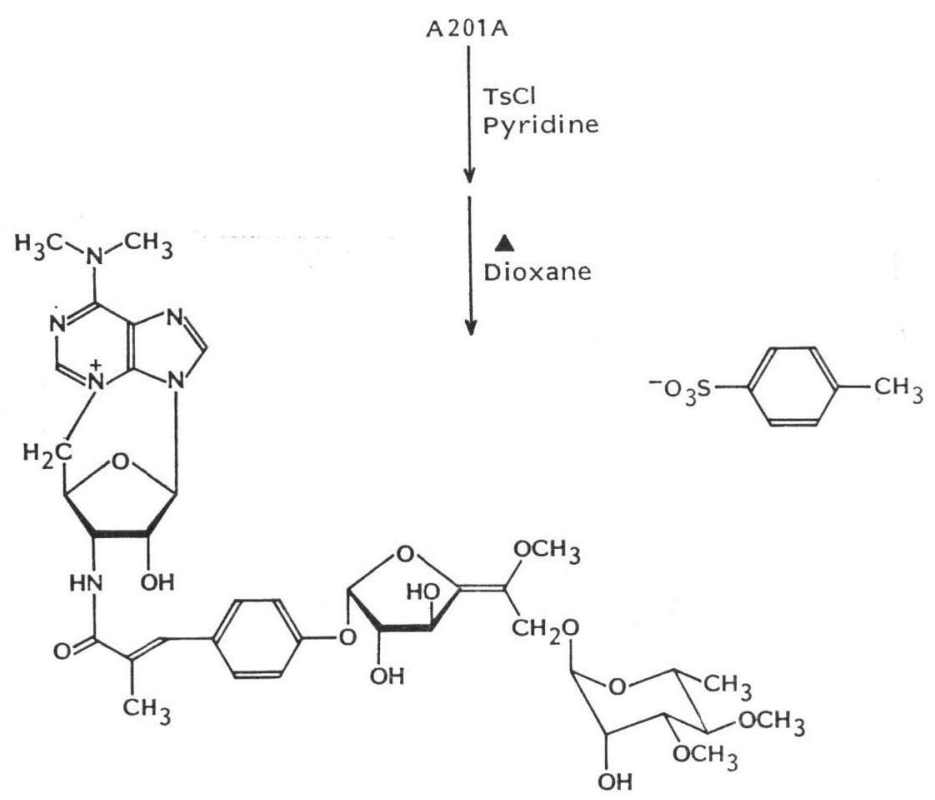

Fig. 6. Structure of minor factors.

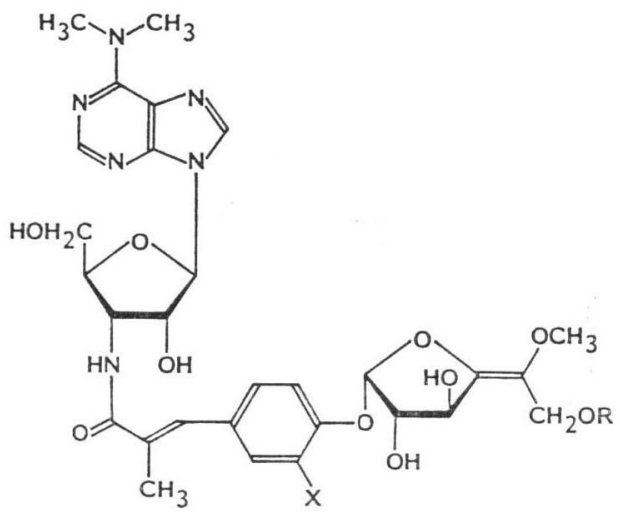

A201A $\mathrm{X}=\mathrm{H}, \quad \mathrm{R}=3,4-\mathrm{Di}-O$-methyl- $\alpha$-rhamnosyl A201C $\mathrm{X}=\mathrm{OH}, \mathrm{R}=3,4-\mathrm{Di}-O$-methyl- $\alpha$-rhamnosyl A201D $X=H, \quad R=H$

A201E $\mathrm{X}=\mathrm{H}, \quad \mathrm{R}=3,4-\mathrm{Di}-O$-methyl- $\alpha$-rhamnosyl, and exocyclic double bond of furanose is saturated.
Table 3. TLC chromatographic movement Trof A201A and related factors.

\begin{tabular}{lcc}
\hline & Rf in solvent $\mathrm{A}^{\mathrm{a}}$ & $\mathrm{Rf}$ in solvent $\mathrm{B}^{\mathrm{b}}$ \\
\hline A201A & 0.48 & 0.31 \\
Hydrolysis & 0.65 & 0.56 \\
$\quad$ product 1 & & \\
A201C & 0.35 & 0.19 \\
A201D & 0.29 & 0.23 \\
A201E & 0.34 & 0.25 \\
\hline
\end{tabular}

a $\mathrm{CHCl}_{3}-\mathrm{EtOH}(6: 1)$, two developments.

b EtOAc - EtOH (6:1), two developments.

In order to resolve the remaining ambiguity concerning the structure and stereochemistry of the central carbohydrate moiety, an X-ray diffraction study of a cyclized derivative (Fig. 5) was undertaken. Formation of the N3 $\rightarrow \mathrm{C}^{\prime}$ cyclo product also served to confirm the $\beta$ stereochemistry at $1^{\prime} .^{14,15)}$ Because of the poor

quality of the crystals, it has not been possible to determine the positions of the atoms at the extreme ends of the molecule. However, the part in question at the center of the molecule was visualized quite clearly, thereby establishing the stereochemistry of the unsaturated sugar and confirming the structural features previously established by the spectroscopic and chemical evidence. It should also be noted that the relative stereochemistry assigned to the unsaturated sugar in A201A is the same as that assigned to the closely related furanose found in the antibiotic hygromycin A. ${ }^{\left.1{ }^{8}\right)}$ The combination of chemical and physico-chemical evidence has thus determined the structure of A201A as that illustrated in Fig. 1. 
In addition to A201A and nucleoside 1, three related antibiotics have been isolated from the fermentation in very minor amounts. ${ }^{17)}$ All three were slightly more polar than A201A (see Table 3) and were purified by repetitive chromatography on silica gel. Their structures were readily assigned once the structure of A201A was determined. A201C had one additional hydroxyl group than did A201A; it was shown by NMR to be attached ortho to the $O$-disaccharide moiety of A201A. The isolation of this minor factor further emphasized the structural similarities of A201A and hygromycin A. ${ }^{16)}$ A201D had the terminal 3,4-di-O-methylrhamnose missing from A201A; it is not certain whether this compound is produced during the fermentation or the isolation procedures. A201E was a dihydro derivative of A201A, in which the unsaturated furanose of the latter had been reduced to the saturated analog. It is thus an isomer of the dihydro A201A which had been obtained by chemical hydrogenation (supra). The relative stereochemistry of the saturated hexofuranose moiety in A201E is still unknown. The interrelationships of these different factors is illustrated in Fig. 6.

From the combination of physico-chemical and chemical evidence presented in this paper, the structures of the novel nucleoside antibiotic A201A and four closely related factors have been definitively established. Their relationships to puromycin and hygromycin A and their mechanism of action as inhibitors of protein synthesis ${ }^{18)}$ should make them interesting candidates for further microbiological studies.

\section{Experimental}

Physico-chemical Determinations

${ }^{1} \mathrm{H}$ NMR spectra were obtained on a Varian HA-100 or a HR-220 NMR spectrometer. ${ }^{13} \mathrm{C}$ NMR spectra were obtained on a Jeol PFT-100 NMR spectrometer. EI mass spectra were obtained on a CEC21-110A or Varian-MAT 731 mass spectrometer; FD mass spectra were obtained on the latter instrument and FAB mass spectra were obtained on a VG ZAB-3F mass spectrometer. UV spectra were measured on a Cary 219 or Cary 118 spectrophotometer. IR spectra were taken on a Beckman 4260 or Perkin-Elmer 221 spectrophotometer. Optical rotations were determined on a Perkin-Elmer 241 polarimeter. Melting points were obtained on a Mel-temp apparatus and are uncorrected.

TLC analyses were performed using E. Merck plates of Silica Gel 60 with a fluorescent indicator (F-254); visualization was effected by either UV light or $p$-anisaldehyde spray reagent. Minor factors were best visualized by scanning the TLC plate on a Schoeffel 3000 scanning spectrodensitometer. Preparative TLC was carried out on preformed silica gel plates (E. Merck, $20 \times 20 \mathrm{~cm}, 2 \mathrm{~mm}$ thick).

\section{Materials}

Puromycin was purchased from Calbiochem and puromycin aminonucleoside was purchased from Sigma Chemical Company.

Isolation of A201A

S. capreolus was grown in a 165 -liter tank for six days as described previously. ${ }^{17,19)}$ The fermentation broth (100 liters) thus obtained was filtered with the aid of Hyflo Super-Cel $(3 \sim 4 \%)$ and the filtrate was first adjusted to $\mathrm{pH} 8.5$ with $5 \mathrm{~N}$ sodium hydroxide and then extracted with an equal volume of chloroform. The chloroform layer was separated and evaporated and the residue was dissolved in methanol $(500 \mathrm{ml})$. Insoluble material was removed by filtration and the filtrate was evaporated to dryness in vacuo. The residue was dissolved in chloroform $(500 \mathrm{ml})$ and diluted with petroleum ether (20 volumes), producing a precipitate which was collected by filtration and dried in vacuo. The crude solid product $(9 \mathrm{~g})$ was dissolved in chloroform $(100 \sim 200 \mathrm{ml})$ and loaded onto a column of silica gel (1.0 liter, Grace 62) which had been packed in chloroform - acetone (1:1). After loading, the column was eluted with chloroform - acetone (1:1,5 column volumes) and then with acetone 
( 5 column volumes). The desired product was located in the various fractions ( 0.5 liter each) by TLC and appropriate fractions were combined and evaporated to dryness in vacuo. The residue was dissolved by warming in a minimal volume of acetone and the resultant solution was allowed to crystallize upon standing overnight at $-20^{\circ} \mathrm{C}$. The crystals thus obtained were collected by filtration and dried in vacuo, yielding a white solid $(1.9 \mathrm{~g}): \mathrm{mp} 170 \sim 172^{\circ} \mathrm{C} ;[\alpha]_{\mathrm{D}}^{25}-129.6^{\circ}(c 1.0, \mathrm{MeOH})$; UV $\lambda_{\mathrm{max}}^{\mathrm{E} t \mathrm{H}}$ $\mathrm{nm}(\varepsilon) 279$ (37,700), 212 (41,600); IR $\nu_{\text {max }}^{\mathrm{CHCl}_{3}} \mathrm{~cm}^{-1} 3570,3420$ (m, br, OH), 1650 (m, amide), 1600 (s); FD-MS $m / z 803(\mathrm{M}+\mathrm{H})$; EI-MS $m / z 454.194395\left(\mathrm{C}_{22} \mathrm{H}_{28} \mathrm{~N}_{8} \mathrm{O}_{5}\right), 292.11953\left(\mathrm{C}_{15} \mathrm{H}_{18} \mathrm{NO}_{5}\right)$; FAB-MS $m / z 803.34524\left(\mathrm{C}_{37} \mathrm{H}_{51} \mathrm{~N}_{6} \mathrm{O}_{14}\right)$; no titratable groups.

Anal Calcd for $\mathrm{C}_{37} \mathrm{H}_{50} \mathrm{~N}_{6} \mathrm{O}_{14}$ : C 55.35, $\mathrm{H} 6.28, \mathrm{~N} 10.47$.

Found:

C 54.70, H 6.16, N 10.38 .

\section{Isolation of $\mathrm{A} 201 \mathrm{C}$}

After the main fractions containing pure A201A had been collected from the silica gel column (supra), elution with acetone was continued to obtain fractions containing A201A along with minor, more polar factors. The fractions were analyzed by TLC, developing the TLC plates two or three times in a solvent system of either chloroform - ethanol (6:1) or ethyl acetate - ethanol (6:1). The minor factors were most conveniently detected by scanning the TLC plate on a Schoeffel 3000 thinlayer scanning densitometer at a wavelength of $275 \mathrm{~nm}$.

The fractions containing both A201A and the more polar factors were pooled from the workup of seven fermentations and the solvent was evaporated under reduced pressure. One-third of this residual dark brown oil (34.8 g) was dissolved in ethyl acetate - ethanol (95: 5), loaded onto a column of silica gel (Grace 62) and eluted stepwise with ethyl acetate - ethanol mixtures (95: 5, 94:6, 92: 8, 90: 10). Elution with ethyl acetate - ethanol (95:5) initially yielded fractions containing only A201A (6.4 g); upon changing to ethyl acetate - ethanol (94:6), a mixture of A201A and A201C was obtained $(2.3 \mathrm{~g})$. Continued elution then yielded fractions containing A201A and A201C along with other factors (see below). Appropriate fractions were pooled on the basis of TLC analyses.

Half of the lot containing only A201A and A201C (1.1 g) was dissolved in chloroform - ethanol (9: 1), loaded on a prepacked silica gel column (E. Merck) and eluted with chloroform - ethanol (9:1) under low pressure. Fractions containing predominantly A201C were combined and evaporated and the residue $(148 \mathrm{mg}$ ) was crystallized from ethyl acetate; the mother liquor was decanted and the precipitate was thoroughly triturated with ether, filtered and dried to yield A201C as a white solid: mp $135 \sim 137^{\circ} \mathrm{C} ;[\alpha]_{D}^{25}-114^{\circ}(c 0.01, \mathrm{MeOH}) ; p K a\left(66 \% \mathrm{DMF}-\mathrm{H}_{2} \mathrm{O}\right) 11.4$; UV $\lambda_{\max }^{\text {EtoH }} \mathrm{nm}(\varepsilon) 279$ $(33,200), 217$ (41,500); $\lambda_{\max }^{\mathrm{pH}}{ }^{11} \mathrm{~nm}(\varepsilon) 325$ (14,200), $268(44,600) ; \mathrm{IR} \nu_{\max }^{\mathrm{CHCl}_{3}} \mathrm{~cm}^{-1} 3350$ (m, br, OH), 1640 (m, amide), 1595 (s); FD-MS $m / z 819(\mathrm{M}+\mathrm{H})$; EI-MS $m / z 470.1883\left(\mathrm{C}_{22} \mathrm{H}_{20} \mathrm{~N}_{8} \mathrm{O}_{6}\right)$; FAB-MS $m / z$ $819.34073\left(\mathrm{C}_{37} \mathrm{H}_{51} \mathrm{~N}_{6} \mathrm{O}_{15}\right)$.

Anal Calcd for $\mathrm{C}_{37} \mathrm{H}_{50} \mathrm{~N}_{6} \mathrm{O}_{15}$ : C 54.27, H 6.16, N 10.26.

Found: $\quad$ C 54.06, H 6.44, N 9.97.

\section{Isolation of A201D}

During chromatographic purification of A201C, a new factor (A201D) was observed eluting after A201C. It was purified from enriched lots $(4.1 \mathrm{~g}$, from column in preceding section) by chromatography on prepacked silica gel columns (E. Merck), eluting with gradients of chloroform - ethanol (95: 5 90: 10). Fractions were combined according to TLC analyses and evaporated, yielding A201D (249 mg) and A201E (693 mg) along with A201C (1.3 g), A201A (1.2 g) and various mixtures of $\mathrm{A}+\mathrm{C}(143 \mathrm{mg}), \mathrm{C}+\mathrm{D}(92 \mathrm{mg})$ and $\mathrm{D}+\mathrm{E}(90 \mathrm{mg})$. A201D was further purified by preparative TLC and then crystallized from methanol as a white solid: $\mathrm{mp} 128 \sim 130^{\circ} \mathrm{C}$; UV $\lambda_{\mathrm{max}}^{\mathrm{EroH}} \mathrm{nm}(\varepsilon) 277(37,000)$, 212 (37,300); IR $\nu_{\mathrm{max}}^{\mathrm{KBr}} \mathrm{cm}^{-1} 3450(\mathrm{~m}, \mathrm{br}, \mathrm{OH}), 1640$ (m, amide), 1600 (s); FD-MS m/z $629(\mathrm{M}+\mathrm{H})$; EI-MS $m / z$ 454; FAB-MS $m / z 629.25823\left(\mathrm{C}_{28} \mathrm{H}_{37} \mathrm{~N}_{6} \mathrm{O}_{10}\right)$.

\section{Isolation of A201E}

While examining samples of A201C and A201D, another factor was noticed which was poorly separated from A201C on TLC plates developed in chloroform - ethanol, but was readily separated on TLC plates developed in ethyl acetate - ethanol. The new factor (A201E) was purified from enriched lots (see preceding section) by chromatography on a prepacked silica gel column (E. Merck), eluting 
with ethyl acetate - ethanol (92:8). Fractions containing A201E were located by TLC analysis, combined and evaporated to dryness to yield a white solid (265 mg); UV $\lambda_{\max }^{\mathrm{EtOH}} \mathrm{nm}(\varepsilon) 278(37,400), 215$ (27,800); IR $\nu_{\max }^{\mathrm{CHCl}_{3}} \mathrm{~cm}^{-1} 3400$ (m, br, OH), 1645 (m, amide), 1595 (s); FD-MS m/z 805 (M +H); EI-MS $m / z$ 454; FAB-MS $m / z 805.36137\left(\mathrm{C}_{37} \mathrm{H}_{53} \mathrm{~N}_{8} \mathrm{O}_{14}\right)$.

Isolation of Hydrolysis Product 1

Material eluting from the silica gel column ahead of the main fractions of pure A201A (see above) were further purified by chromatography on silica gel (Grace 62), using chloroform - ethanol (95:5) as eluent. Fractions containing the desired product were located by TLC analysis, combined and evaporated to yield a yellow-brown solid which was crystallized from acetone, yielding hydrolysis product 1 as a white fibrous solid: $\operatorname{mp} 225 \sim 228^{\circ} \mathrm{C}(\mathrm{dec}),[\alpha]_{\mathrm{D}}^{25}-78^{\circ}(\mathrm{c} \mathrm{0.01}, \mathrm{MeOH}) ; p K a(66 \%$ DMF - $\left.\mathrm{H}_{2} \mathrm{O}\right)$ 11.3; UV $\lambda_{\max }^{\mathrm{EtoH}} \mathrm{nm}(\varepsilon) 282(37,000), 214(30,200) ; \lambda_{\max }^{\mathrm{pH}} 11 \mathrm{~nm}(\varepsilon) 336(23,800), 280(21,300)$; IR $\nu_{\max }^{\mathrm{KBr}} \mathrm{cm}^{-1} 3300(\mathrm{~s}, \mathrm{br}, \mathrm{OH}), 1640\left(\mathrm{~m}\right.$, amide) 1600 (s); EI-MS $m / z 454\left(\mathrm{M}^{+}, \mathrm{C}_{22} \mathrm{H}_{26} \mathrm{~N}_{8} \mathrm{O}_{5}\right), 292$ $\left(\mathrm{C}_{15} \mathrm{H}_{18} \mathrm{NO}_{5}\right)$; FAB-MS $m / z 455.20259\left(\mathrm{C}_{22} \mathrm{H}_{27} \mathrm{~N}_{6} \mathrm{O}_{5}\right)$.

Anal Caled for $\mathrm{C}_{22} \mathrm{H}_{28} \mathrm{~N}_{6} \mathrm{O}_{5}$ : C 58.14, H 5.77, N 18.49, O 17.60. Found: C $58.00, \mathrm{H} 6.02, \mathrm{~N} 17.54$, O 17.83 .

\section{Preparation of Methyl Ether Derivative 2}

A solution of diazomethane in ether $(50 \mathrm{ml})$ was prepared as usual from $N$-methyl- $N$-nitrosourea (54\% dampened with acetic acid, $6.0 \mathrm{~g})$. A solution of nucleoside $1(50 \mathrm{mg})$ in methanol $(25 \mathrm{ml})$ was treated with an aliquot of this diazomethane solution $(2 \mathrm{ml})$ at $5^{\circ} \mathrm{C}$ for 1 minute. After evaporation of solvent, TLC analysis showed considerable starting material remaining, so the residue was redissolved in methanol and treated with an additional aliquot $(5 \mathrm{ml})$ at $5^{\circ} \mathrm{C}$ for 15 minutes. This procedure was further repeated to consume all starting material using $10 \mathrm{ml}$ of diazomethane solution for 30 minutes at $5^{\circ} \mathrm{C}$ and then 15 minutes at $25^{\circ} \mathrm{C}$. Solvent was evaporated under reduced pressure and the residue was triturated with methanol $(2 \mathrm{ml})$; the insoluble product (2) was filtered $(10 \mathrm{mg})$. Repetition of this procedure yielded an additional $11 \mathrm{mg}$ of 2: UV $\lambda_{\max }^{\mathrm{EtOH}} \mathrm{nm}(\varepsilon) 215(32,800), 281(40,700)$ with no shift in acidic or basic solution; MS $m / z 468\left(\mathrm{M}^{+}\right)$; ${ }^{1} \mathrm{H}$ NMR $\left(100 \mathrm{MHz}, \mathrm{DMSO}-d_{6}\right) \delta 3.79(3 \mathrm{H}, \mathrm{s}$, $\mathrm{OCH}_{3}$ ).

\section{Synthesis of Methyl Ether Derivative 2}

Anhydrous $p$-methoxy- $\alpha$-methylcinnamic acid $(192 \mathrm{mg}, 1 \mathrm{mmol})$ and $N$-hydroxysuccinimide $(115 \mathrm{mg}, 1 \mathrm{mmol})$ were dissolved in DMF $(3 \mathrm{ml})$. The solution was cooled in an ice bath and dicyclohexylcarbodiimide $(206 \mathrm{mg}, 1 \mathrm{mmol}$ ) was added. The ice bath was allowed to melt and the mixture was stirred for three days at room temperature. The precipitate was then filtered and the filtrate was evaporated to dryness $(326 \mathrm{mg})$. A portion of this activated ester $(59 \mathrm{mg})$ in DMF $(0.5 \mathrm{ml})$ was added to a solution of puromycin aminonucleoside $(45 \mathrm{mg})$ in DMF $-\mathrm{H}_{2} \mathrm{O}(4: 1,3 \mathrm{ml})$ at $5^{\circ} \mathrm{C}$. The solution was stirred for 16 hours while allowing the ice bath to melt. Solvent was evaporated under reduced pressure and the residue was purified by preparative TLC on two silica gel plates, developing twice in chloroform - ethanol (95:5). The band of desired product was located by UV light and eluted from the silica gel with acetone. After filtration and evaporation of solvent, $50 \mathrm{mg}$ of $\mathbf{2}$ was obtained.

\section{Dihydro A201A}

A201A (205 mg) was dissolved in ethyl acetate $(95 \mathrm{ml})$ and hydrogenated at 1 atm and room temperature over $10 \%$ palladium on carbon $(45 \mathrm{mg})$ for 4 days. The catalyst was filtered and the filtrate was evaporated to dryness. The residue was separated by preparative TLC on two silica gel plates, developing three times with chloroform - ethanol (6:1). The bands of product were located by UV light and eluted from the silica gel with methanol to yield $120 \mathrm{mg}$ of dihydro A201A and $80 \mathrm{mg}$ of tetrahydro A201A. Each product was a mixture of two components due to non-stereospecific reduction of the cinnamamide double bond, as shown by both TLC and NMR analyses. For dihydro A201A: mp 126 $128^{\circ} \mathrm{C}$; UV $\lambda_{\max }^{\mathrm{EtOH}} \mathrm{nm}(\varepsilon) 273(19,900), 215(33,800)$; IR $\nu_{\max }^{\mathrm{CHCl}_{3}} \mathrm{~cm}^{-1} 3420(\mathrm{~m}, \mathrm{br}$, $\mathrm{OH}), 1660$ (m, amide), 1600 (s); MS $m / z 804.353486\left(\mathrm{M}, \mathrm{C}_{37} \mathrm{H}_{52} \mathrm{~N}_{6} \mathrm{O}_{14}\right), 456.21209\left(\mathrm{C}_{22} \mathrm{H}_{28} \mathrm{~N}_{6} \mathrm{O}_{5}\right), 294$ $\left(\mathrm{C}_{15} \mathrm{H}_{20} \mathrm{NO}_{5}\right)$; ${ }^{1} \mathrm{H}$ NMR (100 MHz, DMSO- $\left.d_{6}\right) \delta 0.92 \sim 0.97$ (broad s due to isomers, $2^{\prime \prime}-\mathrm{CH}_{3}$ ). 
Tetrahydro A201A

A201A (296 mg) was dissolved in ethanol $(60 \mathrm{ml})$ and hydrogenated at $1 \mathrm{~atm}$ and room temperature over $5 \%$ palladium on calcium carbonate $(90 \mathrm{mg})$ for 2.5 hours. The catalyst was then filtered and the filtrate was evaporated to dryness. The residue was separated by preparative TLC on two silica gel plates, developing five times in chloroform - ethanol (8:1). The bands of product were located by UV light and eluted from the silica gel with methanol to yield $258 \mathrm{mg}$ of tetrahydro A201A and $29 \mathrm{mg}$ of dihydro A201A. For tetrahydro A201A: UV $\lambda_{\max }^{\mathrm{EtoH}} \mathrm{nm}(\varepsilon) 275(21,100), 220(25,800)$; IR $\nu_{\max }^{\mathrm{CHCl}_{3}} \mathrm{~cm}^{-1} 3420(\mathrm{~m}, \mathrm{br}, \mathrm{OH}), 1656$ (m, amide), 1603 (s); MS m/z 806.3713, 806.3689 (M, $\left.\mathrm{C}_{37} \mathrm{H}_{54} \mathrm{~N}_{8} \mathrm{O}_{14}\right), 456\left(\mathrm{C}_{22} \mathrm{H}_{28} \mathrm{~N}_{8} \mathrm{O}_{5}\right), 294\left(\mathrm{C}_{15} \mathrm{H}_{20} \mathrm{NO}_{5}\right)$; ${ }^{1} \mathrm{H}$ NMR (100 MHz, DMSO-d $\left.d_{6}\right) \delta 0.92 \sim 0.98$ (broad s due to isomers, $\left.2^{\prime \prime}-\mathrm{CH}_{3}\right), 3.26\left(3 \mathrm{H}, \mathrm{s}, 5^{\prime \prime \prime}-\mathrm{OCH}_{3}\right)$.

Hydrogenolysis of A201A

A201A (1.5 g) was dissolved in $95 \%$ ethanol $(300 \mathrm{ml})$, treated with platinum oxide $(510 \mathrm{mg})$ and hydrogenated at $1 \mathrm{~atm}$ hydrogen pressure and room temperature for 5 days. The catalyst was filtered and the filtrate was evaporated. The residue was separated by chromatography on silica gel (Grace $62,150 \mathrm{~g})$, eluting with chloroform - ethanol $(9: 1)$. Fractions were analyzed by TLC and appropriate fractions were combined and evaporated to dryness.

The first material eluted from the column yielded $165 \mathrm{mg}$; crystallization from acetone produced dihydro-1 as a white powder: $\mathrm{mp} 255 \sim 257^{\circ} \mathrm{C}(\mathrm{dec}), \mathrm{pKa}\left(66 \% \mathrm{DMF}-\mathrm{H}_{2} \mathrm{O}\right) 12.5$; UV $\lambda_{\max }^{\mathrm{EtoH}} \mathrm{nm}(\varepsilon)$ 278 (22,500), $218(24,400)$; UV $\lambda_{\max }^{\mathrm{pH}}{ }^{11} \mathrm{~nm}(\varepsilon) 278(19,400), 248(14,800) ; \mathrm{MS} m / z 456(\mathrm{M}) ;{ }^{1} \mathrm{H}$ NMR (100 MHz, DMSO- $\left.d_{8}\right) \delta 0.87 \sim 0.93\left(2^{\prime \prime}-\mathrm{CH}_{3}\right.$, isomers).

Anal Calcd for $\mathrm{C}_{22} \mathrm{H}_{28} \mathrm{~N}_{8} \mathrm{O}_{5}$ : C $57.88, \mathrm{H} 6.18, \mathrm{~N} 18.41$, O 17.53 . Found: C $57.60, \mathrm{H} 6.06, \mathrm{~N} 18.12$, O 17.14 .

After elution of dihydro-1 from the column, a small amount of dihydro A201A was obtained followed by a larger amount of tetrahydro A201A $(923 \mathrm{mg})$. Continued elution then yielded $71 \mathrm{mg}$ of material which was not UV-active but was detected on TLC plates as a blue spot after visualization with anisaldehyde spray reagent. ${ }^{1} \mathrm{H}$ and ${ }^{13} \mathrm{C}$ NMR spectra were consistent with a mixture of disaccharides derived from A201A: FD-MS $m / z 355(\mathrm{M}+\mathrm{H}$ of $4 \mathrm{a})$ and $325(\mathrm{M}+\mathrm{H}$ of $\mathbf{4 b})$.

$30 \mathrm{mg}$ of this material was dissolved in pyridine $(1 \mathrm{ml})$ and treated with acetic anhydride $(0.5 \mathrm{ml})$ at room temperature for 20 hours. After evaporation of solvent, the residual oil $(44 \mathrm{mg})$ was separated by preparative TLC, developing twice with ether. Two bands were observed, which were separated and eluted to yield $7 \mathrm{mg}$ of tetra- $O$-acetyl-4b (MS $\mathrm{m} / \mathrm{z} 492)$ and $18 \mathrm{mg}$ of tetra- $O$-acetyl-4a (MS $\mathrm{m} / \mathrm{z}$ $522)$.

\section{Ozonolysis of A201A}

A201A (200 mg) was dissolved in dichloromethane $(70 \mathrm{ml})$ and cooled to $-15^{\circ} \mathrm{C}$. Ozone was introduced from a generator for 15 seconds at a rate of $1.17 \mathrm{mmol} /$ minute, giving a light blue color. After stirring for 10 minutes, excess ozone was removed by alternate evacuation and flushing with nitrogen. Ozonides were decomposed by addition of $3 \mathrm{ml}$ of a $0.1 \mathrm{M}$ solution of dimethyl sulfide in dichloromethane at $5^{\circ} \mathrm{C}$. After 5 minutes, the mixture was evaporated to dryness. The residue was dissolved in chloroform - ethanol and dried onto a small quantity of silica gel which was then added to the top of a column of silica gel packed in chloroform. After eluting with a small volume of chloroform, the column was eluted with chloroform - ethanol (98:2), yielding $23 \mathrm{mg}$ of $\mathbf{3}$ as a colorless oil: FD-MS $m / z 265(\mathrm{M}+\mathrm{H})$.

\section{N3 $\rightarrow$ C5'-Cyclo-A201A Tosylate}

A201A (401 mg, $0.5 \mathrm{mmol})$ was dissolved in pyridine $(9 \mathrm{ml})$ and treated at $0 \sim 5^{\circ} \mathrm{C}$ with a solution of $p$-toluenesulfonyl chloride $(381 \mathrm{mg}, 2 \mathrm{mmol})$ in pyridine $(3 \mathrm{ml})$. After 1 hour, solvent was evaporated under reduced pressure and the residue was dissolved in a minimum volume of chloroform and applied to a column of silica gel (Grace 62, $25 \mathrm{~g}$ ). The column was packed in and eluted with chloroform - ethanol (96:4). Fractions containing the desired product were located by TLC analysis, combined and evaporated under reduced pressure to give $100 \mathrm{mg}$ of an off-white foam. A portion of this material $(75 \mathrm{mg})$ was dissolved in dry DMF $(5 \mathrm{ml})$ and heated at $75 \sim 80^{\circ} \mathrm{C}$ for 20 hours. The 
mixture was cooled and evaporated to dryness. The residue was crystallized twice from $95 \%$ ethanol

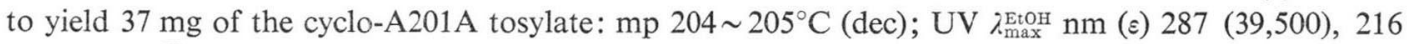
$(46,000) ; \lambda_{\max }^{\mathrm{pH}} 11 \mathrm{~nm}(\varepsilon) 275(29,000)$; IR $2_{\mathrm{max}}^{\mathrm{KBr}} \mathrm{cm}^{-1} 3400$ (m, br, OH), 1620 (m, amide).

\section{$\mathrm{X}$-Ray Data of N3 $\rightarrow \mathrm{C}^{\prime}$-Cyclo-A201A Tosylate}

$\mathrm{N} 3 \rightarrow \mathrm{C}^{\prime}$-Cyclo-A201A tosylate crystallized from $95 \%$ ethanol as fragile colorless needles in the noncentric, orthorhombic space group, $\mathrm{P} 2_{1} 2_{1} 2_{1}$, with 4 molecules in a unit cell having the dimensions, $a=21.12 \pm 0.02 \AA, b=10.008 \pm 0.009 \AA$ and $c=25.77 \pm 0.02 \AA$. The density calculated for $\mathrm{C}_{44} \mathrm{H}_{58} \mathrm{~N}_{8} \mathrm{O}_{18} \mathrm{~S}$ $(\mathrm{M}=957)$ is $1.16 \mathrm{~g} / \mathrm{cm}^{3}$. Because the crystals diffract weakly, intensity data was collected only to $\mathrm{Z} \theta=100^{\circ}$ using an automated four-angle diffractometer with monochromatic copper radiation. Of the 3,172 unique reflections measured, only 1,815 were greater than $3 \sigma_{F}$ and considered observed. The structure was solved by the direct methods programs of the SHELXTL system and partially refined $(\mathrm{R}=0.32)$ by the least-squares method. Because of the very high thermal motion and possible disorder of several atoms on the extreme ends of the molecule, it has not yet been possible to assign accurate positions to these atoms. Further work on this compound awaits better crystals for low temperature studies.

\section{Acknowledgments}

We thank Mr. G. M. MACIAK and associates for elemental analyses and microhydrogenation experiments, Mr. L. A. Spangle and associates for optical rotations and UV and IR spectra, and Mr. R. P. Massing and Mr. J. M. Gilliam for technical help. We also thank Dr. S. C. O'ConNor for the initial isolation of 6-dimethylaminopurine and Dr. E. H. FLYNN for suggesting this project.

\section{References}

1) Kirst, H. A.; D. E. Dorman, J. L. Occolowitz, E. F. Szymanski \& J. W. Paschal: A201A, a new antibiotic produced by Streptomyces capreolus. III. Chemical structure. Abstracts of Papers of 16th Intersci. Conf. on Antimicrob. Agents Chemother., No. 61, Chicago, 1976

2) Suhadolnik, R. J.: Nucleoside Antibiotics. pp. 3 50, Wiley-Interscience, New York, 1970

3) Eggers, S. H.; S. I. Biedron \& A. O. Hawtrey: Mass spectra of puromycin and some derivatives. Tetrahedron Lett. 1966: 3271 3280, 1966

4) Mann, R. L. \& D. O. Woolf: Hygromycin. III. Structure studies. J. Am. Chem. Soc. 79: 120 126,1957

5) МсOмIE, J. F. W.; M. L. WATTS \& D. E. West: Demethylation of aryl methyl ethers by boron tribromide. Tetrahedron 24: 2289 2292, 1968

6) Suhadolnik, R. J.: Nucleoside Antibiotics. pp. 76 86, Wiley-Interscience, New York, 1970

7) Ariatti, M. \& A. O. Hawtrey: Synthesis of cyclohexylpuromycin and its reaction with $N$-acetylphenylalanyl-transfer ribonucleic acid on rat liver ribosomes. Biochem. J. 145: 169 176, 1975

8) Haworth, W. N.; E. L. Hirst \& E. J. Miller: The development of a novel form of stereoisomerism in the sugar series. I. The third variety of triacetyl methylrhamnoside. J. Chem. Soc. 1929: 2469 2479, 1929

9) Fischer, E.; M. Bergmann \& A. Rabe: Uber Acetobromrhamnose und ihre Verwendung zur Synthese von Rhamnosiden. Chem. Ber. 53: 2362 2388, 1920

10) Walker, H. C., Jr.; M. Gee \& R. M. MCCReAdy: Complete methylation of reducing carbohydrates. J. Org. Chem. 27: 2100 2102, 1962

11) Edwards, J. R. \& J. A. Hayashi: Structure of a rhamnolipid from Pseudomonas aeruginosa. Arch. Biochem. Biophys. 111: 415 421, 1965

12) Deslongchamps, P.; P. Atlani, D. Frehel, A. Malaval \& C. Moreau: The oxidation of acetals by ozone. Can. J. Chem. 52: 3651 3664, 1974

13) Wasserman, H. H. \& J. L. Ives: Singlet oxygen in organic synthesis. Tetrahedron 37: 1825 1852, 1981

14) Clark, V. M.; A. R. Todd \& J. Zussman: Nucleotides. VIII. Cyclo nucleoside salts. A novel rearrangement of some toluene-p-sulphonylnucleosides. J. Chem. Soc. 1951: 2952 2957, 1951

15) Mizuno, Y.; M. Ikehara, K. A. Watanabe, S. Suzaki \& T. Itoh: Synthetic studies of potential antimetabolites. IX. The anomeric configuration of tubercidin. J. Org. Chem. 28: 3329 3331, 1963 
16) Kakinuma, K. \& Y. Sakagami: Nuclear magnetic resonance and structure of hygromycin (homomycin). Agric. Biol. Chem. 42: 279 286, 1978

17) Kirst, H. A. (Eli Lilly \& Co.): Antibiotic A201C, A201D, and A201E. US Patent 4,205,164, May 27, 1980

18) Epp, J. K. \& N. E. Allen: A201A, a new antibiotic produced by Streptomyces capreolus. IV. Mode of action studies. Abstracts of Papers of 16th Intersci. Conf. on Antimicrob. Agents Chemother., No. 63, Chicago, 1976

19) Hamill, R. L. \& M. M. Hoenn (Eli Lilly \& Co.): Antibiotics A201A and A201B and process for the production thereof. US Patent 3,843,784, Oct. 22, 1974 